\title{
VALUE RELEVANCE OF ACCOUNTING INFORMATION AND SHARE PRICE: AN EMPIRICAL STUDY ON MANUFACTURING FIRMS IN NIGERIA
}

\author{
Ogbodo, O. C. \\ Department of Accountancy \\ Nnamdi Azikiwe University, Awka \\ Mail: cyogbodo@yahoo.com \\ Osisioma, Benjamin C. \\ Department of Accountancy \\ Nnamdi Azikiwe University, Awka \\ Mail: benosisioma@yahoo.com
}

\begin{abstract}
This study assessed the relationship between the value relevance of accounting information and share price with a focus on manufacturing companies listed on the Nigerian Stock Exchange (NSE). The Ex-post facto research design was used. Ordinary Least Square (OLS) regression analysis and Granger Causality test was used to test the hypothesis with the aid of E-View 9.0. The results of this study revealed that there is a significant positive relationship between Dividend per Share and the Share Price. The researcher recommends among others that standard setters, the stock market regulators and listed manufacturing firms in Nigeria should continuously devise ways of improving the quality of accounting information published in financial statements to maintain and increase their value relevance to the investors and other stakeholders.
\end{abstract}

Keywords: Value relevance, Dividend Per Share, Share Price. 


\section{INTRODUCTION}

All over the world, value relevance of accounting are motivated because listed companies use these data to communicate with investors and the public (Sharma, Kumar \& Singh, 2012). The value relevance of accounting measures, like earnings, the book value of equity, the book value of assets, could be evaluated by the user's response to accounting information provided by reporting companies in any period (Barth, Beaver \& Landsman, 2001).

Baumann and Erlend (2004) documented that financial statements should contain financial and economic reality of a firm to enable users take accurate decisions. Accounting information, such as that conveyed in publicly disclosed accounting reports, is also critical to the analysis of temporal liquidity positions of equity markets (Bushee \& Noe, 2000). As stated by Meyer (2007) accounting plays a significant role in the generation and communication of the wealth of companies. As financial reports remain the most important source of externally feasible information of companies, it importance has led the standards setters and the stock market regulators to continuously devise ways of improving their quality, consequently the need for studies on the relevance of financial statements (Utami \& Noraya, 2010). This study empirically analyzes the value relevance of accounting information and share price reaction of listed companies with a few accounting information indexes such as Dividend per share, from operations.

Value relevance is the most important proxy for quality of accounting reporting, because it provides direct usefulness of accounting information to its end users in the capital market. The relationship between the value relevance of Accounting Information and share prices is stimulating considerable interest across an eclectic range of researchers. Empirical results are sometimes mixed; the results presented in the literature are contradictory. Furthermore, in terms of geographical coverage, to the best of our knowledge no study has been carried out in Nigeria to consider the relationship between value relevance of accounting information and share price in Nigeria. This study seeks to bridge the gap by investigating the relationship between value relevance of accounting information and share price of manufacturing firms in Nigeria representing West Africa and South Africa rather than just firms from Nigeria alone or firms from just West Africa countries. The broad objective of this study is to ascertain the extent Dividend per Share affect Share Price of manufacturing firms in Nigeria.

\section{REVIEW OF RELATED LITERATURE}

\section{Value Relevance of Accounting Information}

In a more detailed discussion, Nilson (2003), value relevance of accounting information deals with the usefulness of financial statement in equity valuation. It investigates the association between the cost of security and accounting variables (Beaver, 2002). Scott, (2003) claimed that accounting information is value relevant if it leads investors to change their beliefs and actions towards investing in a particular stock of a particular firm. To be relevant, accounting data must among others, be quick to respond to users' needs, particularly the investors. 
The primary purpose of the financial statements is to provide information about a firm that will aid users to make better decisions, especially the investors to make optimal investment decisions. (Germon \& Meek, 2001) Financial accounting information should also increase the knowledge of the users and give a decision-maker the capacity to predict the future value of the firm.

Accounting exists primarily to satisfy the users' information, and if this need is not met, those who have money to invest and lend would take the money to where the need for information necessary for their decision to invest are met (Germon \& Meek, 2001). In essence, the investors in particular, should be supplied with information to help them make appropriate appraisals and take a good investment decisions. Value relevance studies involves test whether accounting data are relevant for equity valuation in the local stock market and to relate the results of the test with results obtained by previous researchers of rich countries and draw conclusions about the state of the local economy. Klimczak (2009) states that in both cases value relevance is treated as proof of the quality and usefulness of accounting numbers.

A value relevance study is a concern with the evaluation of the relationship between the accounting information and capital market values (market values). Beaver (2002) indicated that value relevance studies adopting a measurement approach is a combination of valuation theory and accounting theory- contextual accounting and financial reporting arguments that allows the researcher to predict how accounting variables and other information relating to market value will behave.

Holthausen and Watts, (2001) suggest that value relevance studies use two different theories of accounting and standard setting to draw inferences: Direct valuation theory and Inputs-to equityvaluation theory. Direct valuation theory suggests a link between accounting earnings and stock market value. In Direct valuation theory, accounting earnings is intended to measure the changes in equity market values. Zaleha, Muhd-Kamil, Jagjit, and Hamezah (2008) point out that the usefulness paradigm proposes that accounting information is useful if utilized by users of financial statements for, or significantly associated with their decision making. (Riahi-Belkaoui, 2000) stated that even though the information might not be stated at their best current value while (Scott, 2000) is of the view that within this conception, the main users are those who make decisions that relate to the firms' value, specific decision-making by capital market participants.

The Comprehensive Income Statement does not provide any information showing the extent of the value or the wealth created by the company for a particular period. Contribution to the company by other stakeholders cannot be accessed through the Comprehensive Income Statement. Hence, there is a need to modify the existing accounting and financial reporting system so that a business unit can give importance to judge its performance by indicating the value or wealth created by it. To this direction inclusion of the Value Added Statement (VAS) in the financial reporting system is a newly developed technique, which is regarded as a part of social responsibility accounting and reporting (RSiti U \&, Noraya, 2010; Suadiye , 2012).

Financial report has a primary objective of providing the information for investment decision making. Consequent upon this, the usefulness of information contained in financial reports 
depends upon their usefulness for investment decision making (Ghayoumi, Nayeri, Ansari, \& Raeesi, 2011). From the investors' perspective, information is relevant if it contributes to the equity investment decisions of the investor (Glezakos, Mylonakis, \& Kafuoros, 2012). Useful accounting information must possess the primary attributes of relevance and reliability. Relevant accounting information must possess the capacity to influence the decision of the investor (Halonen, Pavlovia, \& Pearson, 2013).

Collins and Kothari (1989) in Pushpa and Sumangala, (2012) concentrated on the stock price change associated with a given unexpected earnings change. It is based on cross-sectional intertemporal data. Ohlson and Juettner-Nauroth, (2005) established a relationship between equity value, earnings yield, change in profitability, change in capital investment, change in growth opportunity and change in the discount rate.

Generally, investors are not in a situation to directly assess the performance of companies in which they intend to invest. They usually depend on financial statements prepared by the management of such an organization. The primary purpose of financial statements is to provide information concerning the financial situation of the company, its operational results, any changes of control in the company, and cash flow (Nirmala \& Florence, 2011). The study impact of financial statement information on capital markets indicators (share price, the volume of trade etc) is referred to as the value relevance studies and it is part of the Capital market-based accounting research. Information is considered 'value relevant' if stock price movements are associated with the release of such information (Holthausen \& Watts 2001). After they empirically studied the correlation between annual report earnings data and stock price, they found that if a company had excess earnings, then investors could get an abnormal return.

\section{Share Price}

A share price is the price of a single share of several saleable stocks of a company. In terms, the stock price is the highest amount someone is willing to pay for a unit of share or the lowest amount that it can be bought for (Lo \& MacKinlay, 2008).

In economics and financial theory, analysts use random walk analysis techniques to model and forecast share prices in the stock markets. This practice is based on the assumption that investors are rational and without biases and at any moment estimate the value of sock based on their future expected returns. According to the random walk share price analysis all existing information available in the market affects the price of the stock, which can only change when new information is made available.

\section{Dividend per Share and Share Price}


Dividend policy is a major financing decision that involves the firm paid back to shareholders in return for their investments in the shares of the company. The demand for the firm's share should to some extent, dependent on the firm's dividend policy.

Selecting a suitable dividend policy is an important decision for the firm because the flexibility to invest in future projects depends on the number of dividends that they pay to their shareholders. If a company pays more dividends, then little funds will be available for investment in future projects. Borrowers/Lenders are also interested in the amount of dividend that a company declares, because if more amounts is paid as dividend from the firm's earnings, that means less amount would be available to the company to pay off their obligations.

Kalama, (2013) said that dividends are the only cash payment a stockholder receives directly from a firm and these are the foundation of valuation for common stocks. Stock price response to an unexpected dividend change announcement, but the shareholder's reaction to dividend change announcement is related to the dividend preferences of the marginal investor in from other firms being equal (Dong, Robinson \& Veld, 2005). When a company changes its dividend policy, it is expected to experience upward or downward trends in share price (Yilmaz, \& Gulay, 2006).

Dividend per share (DPS) is the sum of dividends declared by a company for every ordinary share outstanding. It is the total dividends paid by the firm including interim dividends divided by the total number of outstanding ordinary shares issued by the company. Dividend per share of a company is derived using the dividends paid in the most recent quarter. DPS is calculated with the following formula:

$$
\mathbf{D P S}=\underline{\mathbf{D}-\mathbf{S}}
$$

\section{S}

Where,

D - Sum of dividends over a period (usually one (1) year)

SD - Special, one time dividends

S - Shares outstanding for the period

Dividend per share is important because the number one goal of a company is to return value to its shareholders. Investors receive value through dividend payments and appreciation in the price of the stock itself. Therefore, a company's profits and the amount it pays out in dividends, drives shareholder value (Ryan, 2017).

\section{Review of Related Studies}

Several works of literatures now exist which investigates the value relevance of accounting information to stock price and different scenario was found in different studies. Bankole and Ukolobi (2020) examined the value reliance of accounting information in financial service companies in Nigeria. The study used data from 2012-2018 of 20 financial service companies listed in the Nigerian Stock exchange. Eviews 10 was used to analyze the data collected for this study. Least square regression method was adopted to make our statistical decisions. After 
conducting Hausman Test, the result indicated that random effect is more appropriate than the fixed effect model. There is positive and significant relationship between share price and firm size. The study also found that there is negative and insignificant relationship between DPS, EPS, CFO, BVS and SP. The study concluded that there is relationship between share price and firm size. Also we conclude that there is no value relevance between information in financial statements and share price. Pushpa and Sumangala, (2012) examined the impact of Earnings per share (EPS) on the market value of an equity share in the Indian context. The study is based on data from 50 companies over a period of 5 years. The study concluded that EPS have impact on the market value of an equity share in the Indian context. Omokudu, (2012) ascertained the value relevance of accounting information for firms quoted in Nigeria Stock exchange for 20 years period from 1990 to 2009 . The result of the study indicates that the coefficient estimates of earnings, cash flow and dividend were significantly valued relevant and cash flow from operations were more incrementally value relevant over earnings. Mgbame and Ohiorenuan, (2013) determined whether accounting information contributes to stock volatility in the Nigerian Capital Market. Secondary data retrieved from the financial statements of the sampled companies were employed for the study. E-views 7.0 was utilized for data estimation. Findings from the study revealed that there are enough evidence to reject the assumptions of conditional normality in stock prices data series and accept the existence of stock volatility in Nigerian stock market. Daye (2013) examined the empirical relationship between earnings and equity share prices of 42 sampled companies listed at the Nairobi Securities Exchange (NSE) from 2007 to 2012. Multiple linear regression analysis was used to establish the relationship between the dependent variable (Share price) and earnings per share (EPS) the explanatory variable. It was also found that there were other variables significantly correlated with share price. Adaramola and Oyerinde (2014) examined the value relevance of accounting information of quoted companies in Nigeria using trend analysis. The study employed Ordinary Least Square (OLS) regression method of data analysis. The study show that accounting information of quoted companies in Nigeria is value relevant; however, the value relevance of accounting information does not follow a particular trend within the period under study. Ivica and Marijana, (2014) analyzed value relevance of accounting information based on a sample of 97 corporations listed in the following capital markets: Ljubljana Stock Exchange, Zagreb Stock Exchange, Sarajevo Stock Exchange, Banja Luka Stock Exchange and Belgrade Stock Exchange. The study results show that accounting information is value relevant to all the observed markets. Manisha, (2014) analyzed the combined, individual and incremental value relevance of accounting information produced by firms listed on the S\&P BSE-500 for the financial year 2006 to 2010 and changes therein over the period. It was also found that the combined value relevance of accounting information represented by earnings per share and book value per share has declined while there have been insignificant changes in the incremental value relevance of accounting information. Ordu, Enekwe and Anyanwaokoro, (2014) conducted a study on the effect of dividend payment on the market prices of shares in Nigeria: A study of 17 quoted firms using time series data on dividend per share, dividend yield, and dividend payout ratio for the period 2000 to 2011. Ordinary least squares were used for the analysis of the data collected. The researchers' empirical results arising from the panel least squares suggest a positive effect between market price per share and dividend per share confirming that a rise in dividend per share brings about an increase in the market price per share of quoted firms. Anike, (2014) examined the impact of 
dividend yield on stock prices of Nigerian banks; the impact of earnings yield on stock prices of Nigerian banks and the impact of payout ratio on stock prices of Nigerian banks. The Ordinary Least Square Regression Model was used to estimate the relationship between the independent variables - dividend yield, earnings yield and payout ratio and stock prices and the dependent variable- Share price (Daily stock price average was used). The result from this study indicates that dividend yield has a negative and significant influence on stock prices of commercial banks in Nigeria, earnings yield had a negative and significant impact on stock prices of commercial banks in Nigeria and finally, dividend payout ratio had a negative and non-significant impact on stock prices of commercial banks in Nigeria. Oloidi and Bolade (2015) analyzed the major variables that determine the equity shares prices of listed companies on the Nigerian Stock Exchange using their accounting data as published for the financial year 2011/2012. The result of the study revealed that the prior year share price significantly and positively influenced equity share price at $\alpha=0.000$, earnings per share was negatively significant at $\alpha=0.05$ and dividends per shares had a positive and significant influence on the equity share price at $\alpha=0.014$. Musa (2015) determined the value relevance of accounting information in listed Industrial Goods firms in Nigeria using data obtained from the Nigerian Stock Exchange Factbook and the daily price list on the Cash Craft website from 2007-2013. Ordinary Least Square (OLS), Fixed Effects (FE) and Random Effects (RE) models were employed as tools of analysis but after conducting relevant tests, REM is used in testing the hypotheses of the study The results revealed that all the explanatory variables statistically and significantly influence the explained variable. Umobong and Akani, (2015) investigated the differences in the quality of accounting information of manufacturing firms in Nigeria pre and post IFRS adoption. Secondary data from financials of a sample of 4 listed cement manufacturing firms and 7 listed breweries companies was collected for five years period 2009-2013. Multiple regression analysis was perform on the accounting variables and t-test was carried out for equality of mean to compare pre and post IFRS. Findings of their study indicate a decline in accounting quality using earning management, Value relevance, and timely loss recognition as independent variables. Olubukola, Uwalomwa, Jimoh, Ebeguki and Olufemi, (2016) examined the value relevance of financial statements on share price of firms in Nigeria by examining the relationship between earnings and share prices of the firms. Findings from the study showed that a significant positive relationship exist between earnings per share (EPS) and share price. The study recommends the need for banks in the country to improve on the quality of the earnings reported in their financial statements, since earnings has a stronger ability in explaining share prices of firm. Samuel and Pradeep, (2016) sought to found out the firms' factors that determine their share market prices. Based on the objective of their study, fourteen (14) companies listed on the Johannesburg stock exchange from period the 2009-2013 was selected for the study. Multiple regression analysis statistical tool was use to analyzed the secondary data collected on the firms., the independent variables for the study were dividend per share, earnings per share, and price-earnings ratio and the dependent variable was the share prices. The study found that dividend per share, earnings per share, and price-earnings ratio account for about $57.8 \%$ of share prices changes in the market. Mayadunne, (2017) analyzed the value relevance of accounting information on investor's decisions. Market prices were used as dependent variable and return on equity, earning yield, net assets value per share, earning per share were used as independent variables. 


\section{METHODOLOGY}

The research design employed in this study is ex-post facto research design. An Ex-post Facto research determines the cause-effect relationship among variables. Ex-post Facto seeks to find out the factors that are associated with certain occurrence, conditions, events or behaviours by analyzing already existing data.

\section{Population and Sample Size and Sampling Method}

The population of this study comprises of the sixty (60) manufacturing firms listed on NSE during the ten year period 2010-2019 as at December 2019. Conditions (Elimination) Sampling Method was adopted to select thirty manufacturing firms from NSE. To select the sample firms, sample selection technique is performed by the following criteria: sampled firm is listed each year on the NSE from 2010 to 2019. The firm provides complete financial statements for December 31 and successively registered with the NSE.

\section{Method of Data Analysis}

This study employed Ordinary Least Square (OLS) estimate using panel data from 2010 to 2019 covering a period of ten years for 62 manufacturing firms, to estimate and provide evidence on the nature of the relationship between accounting information and share price. This was carried out, using coefficient of correlation which is a good measure of the relationship between two variables, in order to show the strength of the relationship and the direction of relationship as well. OLS Regression Analysis was used with the aid of E-view 9.0 statistical software.

\section{Model Specification}

The researcher therefor modified the Ohlson (1995) Model as follows:

$\mathrm{SP}_{i t}=\beta \mathrm{o}+\beta_{1} \mathrm{DPS}_{i t}+£_{i}$ i

Where:

$\mathrm{SP}_{i t}=$ share price for firm ${ }_{i}$ at the end of year $\mathrm{t}$

$\mathrm{DPS}_{i t}=$ dividends per share for firm $\mathrm{i}$ at the end of year $\mathrm{t}$

$£=$ error term (part of the share price which is not interpreted by the model)

$\beta \mathrm{o}=$ the intercept

$\beta_{1}$ is the coefficient of explanatory variable.

Accept the alternative hypothesis $\left(\mathrm{H}_{1}\right)$ if the p-value of the test is less than 0.05 , otherwise reject. 
Journal DOI: 10.46654/ij.24889849

Vol. 6, Issue 12 (December, 2020) | www.ijaar.org

Article DOI: 10.46654/ij.24889849.s2122

\section{DATA ANALYSIS AND INTERPRETATION}

\section{Test of Hypothesis}

Ho: There is no significant relationship between Dividend per Share and Share Price of manufacturing firms in Nigeria.

Table 1: Regression analysis output for SP and DPS of quoted manufacturing companies in Nigeria

Dependent Variable: SP

Method: Least Squares

Date: 21/12/20 Time: 08:02

Sample: 1380

Included observations: 10

\begin{tabular}{lllll}
\hline \hline Variable & Coefficient & Std. Error & t-Statistic & Prob. \\
\hline \hline C & 3.443137 & 0.144482 & 23.83086 & 0.0000 \\
DPS & -0.102936 & 0.132995 & -2.773981 & 0.0314 \\
\hline \hline R-squared & 0.001582 & Mean dependent var & 3.386559 \\
Adjusted R-squared & -0.001059 & S.D. dependent var & 2.428117 \\
S.E. of regression & 2.429402 & Akaike info criterion & 4.618417 \\
Sum squared resid & 2230.954 & Schwarz criterion & 4.639154 \\
Log likelihood & -875.4991 & Hannan-Quinn criter. & 4.626645 \\
F-statistic & 4.599047 & Durbin-Watson stat & 1.486251 \\
Prob(F-statistic) & 0.031426 & & \\
\hline \hline
\end{tabular}

Source: E-Views 9.0 Co-integration output, 2020

Table 2: Granger Causality test showing the Causality between SP and DPS of manufacturing companies in Nigeria

Pairwise Granger Causality Tests

Date: 12/06/17 Time: 08:27

Sample: 1380

Lags: 2

\begin{tabular}{lccc}
\hline \hline Null Hypothesis: & Obs & \multicolumn{2}{c}{ F-StatisticProb. } \\
\hline \hline DPS does not Granger Cause SP & \multirow{2}{*}{378} & 4.64576 & 0.0122 \\
SP does not Granger Cause DPS & & 0.20042 & 0.8185 \\
\hline \hline
\end{tabular}

Source: E-Views 9.0 Causality output, 2020 
Journal DOI: 10.46654/ij.24889849

\section{Interpretation of Regression Output}

Table 2 shows the output of regression for overall sample on public listed manufacturing companies in Nigeria and South Africa and the result for the model can be written as follows:

$S P_{i t}=3.932849+0.274009 \mathrm{DPS}_{i t}+£_{i t}$

The result shows that at $95 \%$ confidence level, DPS have a significant positive relationship towards Share Price for companies listed on Nigeria and Johannesburg Stock Exchange following the F-statistics of 5.311669 with $\mathrm{p}<0.05$. Therefore, hypothesis $\mathrm{H}_{1}$ is accepted. Based on t-statistics, the result further indicates that the independent variable (DPS) is significant in determining share price. It can be inferred that a $1 \%$ increase in DPS, the share price increases by $27.40 \%$ per year.

The Durbin-Watson Value of 1.208817 buttressed the fact that the model does not contain autocorrelation, thereby, making the regression fit for prediction purpose. The R-Squared of 0.35 shows that $35 \%$ of the systematic variation in SP could be explained by DPS, while the remaining $65 \%$ is explained by the error term as part of the share price which is not interpreted by the regression model.

\section{Decision}

The significant relationship that is displayed in the output result contradicts with the hypothesis developed earlier saying that there is no significant relationship between Dividend per Share and

The study was to establish the relationship between dividend per share (DPS) and share price (SP) of manufacturing firms listed in the Nigeria. Consequently, the null hypothesis was also formulated in line with this objective and was tested using regression analysis at $5 \%$ level of significance. The test result shows that there is significant positive relationship between dividend per share (DPS) and share price (SP) of manufacturing firms listed in the Nigeria stock market. This result agrees with the findings of Daye, (2013); Philip \& John, (2016); Edward, (2014) and Musa (2015) who all found a significant positive correlation between share price and dividend.

\section{CONCLUSION AND RECOMMENDATIONS}

This study examined the relationship between value relevance of accounting information and Share Price of manufacturing sector in Nigeria. Existing literature showed that researchers are yet to reach a consensus about the relationship between value relevance of accounting information and Share Price. Data analysis revealed that a relationship exists between Dividend Per Share and share price of manufacturing sector in Nigeria. As disaggregated components, Dividend Per Share exerted significant positive relationship with Share Price at $5 \%$.

The following recommendations were proffered from the findings and conclusion of this study: Dividend policy should be such that allow the possibility of paying regular dividend since dividend is found to have impact on their share price. This is because dividends play vital role in investors' decision making on the companies on the trading exchange. 


\section{References}

Adaramola, A.O, \& Oyerinde A.A. (2014). Value relevance of financial accounting information of quoted companies in Nigeria: A trend analysis, Research Journal of Finance and Accounting, 5(8), 86-94.

Anike, E.A. (2014). The impact of dividend policy and earnings on stock prices of Nigeria banks. A dissertation submitted to the Department of Banking \& Finance, Faculty of Business Administration, University of Nigeria, Nsukka.

Barth, M. E., Beaver, W.H., \& Landsman, W.R. (2001). The relevance of the value relevance literature for financial accounting standard setter: Another view. Journal of Accounting and Economics, 31(1-3), 77 - 104.

Baumann, U., \& Erlend, N. (2004). Disclosure, volatility, and transparency: An empirical investigation into the value of bank disclosure. Federal Reserve Bank of New York Economic Policy Review, 31-45.

Beaver, W. H. (2002). Perspectives on recent capital market research. Accounting Review, 77(2), 453-474.

Bankole, K. O. \& Ukolobi, I. O. (2020). Value relevance of accounting information and share price in financial service industry. Research Journal of Finance and Accounting. 11(8),ISSN 2222-1697 (Paper) ISSN 2222-2847 (Online) www.iiste.org

Bushee, B. J. \& Noe C. F. (2000). Corporate disclosure practices, institutional investors and stock return volatility, Journal Of Accounting Research (studies on accounting information and the economics of the firm), 171-202.

Chen, C. J P., Chen, S., \& Su, X. (2001). Is accounting information value relevant in the emerging Chinese stock market? Journal of International Accounting Auditing \& Taxation, 10(2), 112.

Collins, D., \& S., P., Kothari, (1989), An analysis of cross-sectional and intertemporal determinants of earnings response coefficients. Journal of Accounting and Economics 11(2-3) 143-181.

Daye, J.K. (2013). The relationship between earnings and share prices of firms listed at the Nairobi Securities Exchange. A research project report submitted for the award of the Degree of Master of Business Administration, School of Business, University of Nairobi, $1-60$.

Dong, M., Robinson, C., \& Veld, C. (2005). Why individual investors want dividends. Journal of Corporate Finance, 1 (12), 121-158.

Germon, H. \& Meek, G. K. (2001). Accounting: An International Perspective. McGraw Hill: Singapore.

Ghayoumi, A. F., Nayeri, M. D., Ansari, M., \& Raeesi, T. (2011). Value relevance of accounting information: Evidence from Iranian Emerging Stock Exchange. World Academy of Science, Engineering and Technology,78. Retrieved from http://waset.org/publications/15331/value-relevance-of-accounting-informationevidence

Glezakos, M., Mylonakis, J. \& Kafuoros, C. (2012). The impact of accounting information on stock prices: Evidence from Athens stock exchange.

Halonen, E., Pavlovia, J. , \& Pearson, R. (2013). Value relevance of accounting information and its impact on stock prices: Evidence from Sweden. Department of /economics Stockholm 
University abstract : Final version of value relevance of act data evidence. Retrieved 16th December, 2014.

Holthausen, R.W., \& Watts, R.L. (2001). The relevance of the value relevance literature for financial accounting standard setting. Journal of Accounting \& Economics. 31(3), 3-75. http://dx.doi.org/10.1016/S0165-4101(01)00029-5

Ivica, P. \& Marijana, B.(2014). Value relevance of accounting information: Evidence from South Eastern European countries, Economic Research-Ekonomska Istraživanja, 27(1), 181-190, DOI: 10.1080/1331677X.2014.947132.

Kalama, K. D. (2013). The relationship between earnings and share prices of firms listed at the Nairobi stock exchange. Unpublished MBA Project, University of Nairobi.

Klimczak, K.M. (2009). Testing value relevance of accounting earnings in emerging markets, http://kmklim.republika.pl/ekonomia/resource/kmklimczak_GAT_200 pdf, retrieved 26 August, 2010.

Lo, A. W.; \& A. C. MacKinlay (2008). Stock market prices do not follow random walks: Evidence from a simple specification test. Review of Financial Studies. 1 (1): 41-66. $\underline{\text { ISSN 0893-9454. doi: } 10.1093 / r f s / 1.1 .41 . ~ R e t r i e v e d ~ 11 ~ M a r c h, ~} 2011$.

Manisha, K. (2014). Value relevance of accounting information: An empirical study of selected Indian firms. International Journal of Scientific and Research Publications, 4(10), 1-6.

Mayadunne, M. (2017). An empirical study of the value relevance of accounting information on market price in sub financial sectors in Sri Lanka. Department of Accountancy and Finance, South Eastern university of Sri Lanka, Oluvil, Sri Lanka, 1-16.

Meyer, C. (2007). Shareholder value accounting - the value relevance of financial statement data and the determinants of accounting method choices. http://www.research.unizh.ch. Retrieved 22nd June, 2016

Mgbame, C.O., \& Ohiorenuan, J. I. (2013). Accounting information and stock volatility in the Nigerian capital market: A Garch analysis approach. International Review of Management and Business Research, 2(1), 265-281

Muhammed S.M., (2012). Value relevance of accounting information and stock market vulnerability - A study on listed companies in Dhaka Stock Exchange, in: Int. J. Res. Commerce and Manag. 3, 23-27.

Muhammad, A.C ( 2017): IFRS adoption and Value Relevance of Accounting Information: A study of Listed Insurance Firms in Nigeria. a dissertation submitted to the School of Postgraduate Studies, Ahmadu Bello University, Zaria, for the Award of Master of Science Degree (M.Sc) in Accounting and Finance .

Nilson, H.(2003). Essays on the value relevance of financial statement information. Working Paper, Umea Universitet.

Nirmala, S. (2012). Value relevance of published financial statements- With special emphasis on impact of cash flow reporting, International Research Journal of Finance and Economics, 17, 84-90.

Nirmala N., \& Florence J (2011). Value relevance of accounting information. Journal of Financial. Accounting. Management. 2,(1), 16-26. 
Journal DOI: 10.46654/ij.24889849

Ohlson, J., \& Juettner-Nauroth, B. (2005). Expected earnings per share and earnings per share growth as determinants of value, Review of Accounting Studies 10(2-3) 349-365.

Oloidi, G.A., \& Bolade, S. K. (2015). An empirical determinant of equity share price of some quoted companies on the Nigerian stock exchange. International Journal of research and Development Organisation. 1(8), 26-43.

Olubukola, R. W., Uwalomwa, U., Jimoh, J. Ebeguki, E.I., \& Olufemi, A.O. (2016). Value relevance of financial statements and share price: A study of listed banks in Nigeria, Banks and Bank Systems, 11(4),135-143.

Omokudu, O.O (2012): Relevance of Accounting information to secondary capital market: Case of Nigeria stock exchange . Being a dissertation submitted to the School of Postgraduate Studies, University of Benin, for the Award of Ph.D, Department of Accounting.

Ordu M. M., Enekwe, C.I., \& Anyanwaokoro, M. (2014). Effect of dividend payment on the market price of shares: A study of quoted firms in Nigeria. IOSR Journal of Economics and Finance, 5,(4). 49-62.

Pushpa, B., \& Sumangala, J.K. (2012). Impact of Earnings per share on Market Value of an equity share: An Empirical study in Indian Capital Market. Journal of Finance, Accounting and Management, 3(2), 1-14

Riahi Belkaoui, A. (2000). Accounting theory (4th ed.). London: Thomson Learning.

RSiti U., \& Noraya S. (2010). Significance of accounting information in explaining market and book values: The Case of Indonesian Banks, Int. Res. J. Fin. Econ. 55

Samuel, T. E., \& Pradeep, B. (2016). Determinants of share prices: The case of listed firms on Johannesburg stock exchange. The Journal of Accounting and Management, 6(1).

Scott, W. R. (2000). Financial accounting theory (2nd ed.). Ontario: Prentice-Hall Canada Inc.

Sharma, A, Kumar, S, \& Singh, R.(2012). Value relevance of financial reporting and its impact on stock prices: Evidence from India. South Asian Journal of Management. 19(2), 60-77.

Steven. N. (2015). How can you calculate book value of equity per share (BVPS) in Excel? http://www.investopedia.com/ask/answers/050715/how-can-you-calculate-book-valueequity-share-bvps-excel.asp\#ixzz4wUT0x1lr

Suadiye G (2012). Value relevance of book value and earnings under the local GAAP and IFRS: Evidence from Turkey. Ege Akademik,Review, 12(3), 301-310.

Tharmila. K. \& Nimalathasan, B. (2013). The value relevance of accounting information and its impact on market vulnerability: A study of listed manufacturing companies in Sri Lanka. Merit Research Journal of Business and Management, 1(2) , 030-036, December, 2013. Available online http://www.meritresearchjournals.org/bm/index.htm

Umobong, A. A. \& Akani, D. (2015) : IFRS adoption and Accounting Quality of Quoted Manufacturing Firms in Nigeria: A Cross Sectional Study of Brewery and Cement Manufacturing Firms, European Journal of Accounting, Auditing and Finance Research. Vol 3, No 8, pp 77-85 August 2015.

Utami, R. S. \& Noraya. S. (2010). Significance of accounting information in explaining Market and book values: the case of Indonesian banks. International Research Journal of Finance and Economics, 55 
International Journal of Advanced Academic Research (Social and Management Sciences) | ISSN: 2488-9849

Journal DOI: 10.46654/ij.24889849

Vol. 6, Issue 12 (December, 2020) | www.ijaar.org

Article DOI: 10.46654/ij.24889849.s2122

Yilmaz, AK \& Gulay, G. (2006) Dividend policies and price-volume reactions to cash dividends on the stock market: Evidence from the Istanbul Stock Exchange, Emerging Markets Finance and Trade, 42(4), 19-49.

Zaleha, A.-S., Muhd-Kamil, I., Jagjit, K., \& Hamezah, M.-N. (2008). The value relevance of intangibles non-current assets in different economic conditions. International Review of Business Research Papers, 4 (2), 316-337. 